\title{
Technological Properties of Wheat-Triticale-Rye Flour
}

\author{
Roman Khazhsetovich Kandrokov ${ }^{1 *}$, Natalia Aleksandrovna Berezina ${ }^{2}$, Irina Uruzmagovna \\ Kusova ${ }^{1}$ and Aleksandr Alekseevich Ryndin ${ }^{1}$ \\ ${ }^{1}$ Department of Grains, Bakery and Confectionery Technologies, Institute "Food Systems and Health-Saving Technologies", \\ Moscow State University of Food Production Volokolamskoye shosse 11, Russia
}

${ }^{2}$ Federal State Budgetary Educational Institution of Higher Education "Oryol State Agrarian University named after N.V. Parakhina", Generala Rodina st., 69, Oryol, Russia

*Corresponding author: Kandrokov, Department of Grains, Bakery and Confectionery Technologies, Institute "Food Systems and Health-Saving Technologies", Moscow State University of Food Production Volokolamskoye shosse 11, Moscow, Russia

\section{ARTICLE INFO}

Received: 㠈 October 06, 2021

Published: 慧 October 20, 2021

Citation: Roman Khazhsetovich Kandrokov, Natalia Aleksandrovna Berezina, Irina Uruzmagovna Kusova, Aleksandr Alekseevich Ryndin. Technological Properties of Wheat-Triticale-Rye Flour. Biomed J Sci \& Tech Res 39(3)-2021. BJSTR. MS.ID.006305.

Keywords: Wheat; Triticale; Rye; Grain Mixture; Clearance Yield; Wheat-TriticaleRye Flour; Baking Properties

\section{ABSTRACT}

Background and Objective: the purpose and objectives of the research is to develop a technology for processing wheat-triticale-rye grain mixture and determine the baking properties of the obtained wheat-triticale-rye flour.

Material and Methods: Wheat grain line 5170, triticale grain Alexander and winter rye grain Moscovskaya 12 of 2017 were used as the objects of study. The baseline of wheat and triticale grain quality was determined by the infra-red analyzer of grain SpectraStar $2500 \mathrm{XL}$ and is presented on Table 1 . The quality evaluation of the obtained samples of wheat-triticale-rye flour was carried out in accordance with standards of GOST (State Standardization System) 26574 -2017 "Wheat bread flour. Technical specifications", GOST 34142-2017 "Triticale flour. Technical specifications" and GOST 7045-2017 "Rye bread flour. Technical specifications".

Results and Conclusion: In this paper, for the first time, comprehensive studies were carried out to determine the milling and baking properties of wheat -triticale- rye flour samples obtained by co-processing a grinding grain mixture of wheat, triticale and rye grain at the "Melnic 100 Lux" industrial mill. To determine and compare the milling and baking properties, we processed the original wheat grain and the grinding mixtures of wheat and triticale grain in proportions 50:40:10, 50:35:15, 50:30:20. According to the results of conducted tests it can be concluded that the original grinding mixture of wheat, triticale and rye grain in proportions 50:40:10 is the most optimal. In such proportions the yield and of high-grade flour and the total yield of flour is the highest and exceeds not only all other grinding wheat-triticale-rye grain mixtures but the control sample of wheat as well. In addition, the flour obtained from that grain grinding mixture has the highest whiteness typical of the highest quality flour. According to the results of the test laboratory baking it has been established that bread from wheat-triticale- rye in proportions of 50:40:10 has the most optimal quality indicator and is most similar to the control version of wheat bread.

\section{Introduction}

In the diet of the population of this country a large proportion (up to $40 \%$ ) is taken by breadstuffs, the main part of which are products on the basis of various kinds of baking and macaroni flour. So, it looks quite promising and much in demand to make flour composite mixtures at flour mills with the specified contents of the main nutritious and biologically active substances: protein, carbohydrates, carbs, fats, vitamins, micro- and macro elements from the products of the main processed crops including wheat, triticale and rye. Such grain mixtures will become basic for particular manufactures which make bakery products, confectionary, pasta 
and extruded products, dairy and meat products for specific diet: dietary, preventive and curative nutrition [1-11,12-26]. The current trends in the development of one of the most important processing industries - flour grinding - are developing technologies of processing traditional crops (wheat and rye) as well as new technologies of processing non-traditional crops such as triticale. The ultimate goal of the branch development is to introduce new and to improve traditional technologies and to create products of procession of various kinds of crops with a specified composition and qualities. In addition, a co- processing of grain of various crops, including wheat, triticale and rye is most promising [1$6,17,22,23]$. Breadstuffs with products of processed triticale grain are characterized by higher nutritional value since there is more protein and indispensable amino acids, the main limiting acid lysine. The combination of positive properties of rye - abundance of biologically active aromatic substances and wheat - rheological properties of dough makes it possible to make diet products.

Wheat protein has little lysine, so in the course of breadstuffs production of improved composition products the lack of lysine is compensated by the increase in digestibility and nutritional value of the product [14].

\section{Materials and Methods}

Wheat grain line 5170, triticale grain Alexander and winter rye grain Moscovskaya 12 of 2017 were used as the objects of study. The baseline of wheat and triticale grain quality was determined by the infra-red analyzer of grain SpectraStar $2500 \mathrm{XL}$ and is presented on Table 1 . The quality evaluation of the obtained samples of wheattriticale-rye flour was carried out in accordance with standards of GOST (State Standardization System) 26574 -2017 "Wheat bread flour. Technical specifications", GOST 34142-2017 "Triticale flour. Technical specifications" and GOST 7045-2017 "Rye bread flour. Technical specifications". The grain is grinded at a roller mill "Melnic 100 Lux". The capacity of the mill is up to $100 \mathrm{~kg} / \mathrm{hr}$. and it grinds the grain of various crops into the flour of the higher-grade flour, class 1 and class 2 . Cold air conditioning as the most common method was used as hydrothermal treatment. The original grain of wheat and wheat-triticale-rye grain mixture was moisturized up to $15.0-15.5 \%$ and was swelling up for 10 hours. In the course of grinding various sorts of triticale grain the mechanical-kinematic parameters of rollers (spacing between rollers, gradient of riffles, number of riffles per $1 \mathrm{~cm}$. location of riffles, balance between rapidly rotating and slowly rotating rollers, the speed of the rapidly rotating roller) and the set of strainers was unchanged.

Table 1: Indicators of the original wheat and triticale grain quality.

\begin{tabular}{|c|c|c|c|}
\hline Indicators of Quality & Wheat Line5170 & Triticale Alexander & Rye Moskovskaya 12 \\
\hline Moisture content \% & 8.3 & 9.2 & 10.5 \\
\hline Fat content $\%$ & 1.13 & 1.3 & 1.12 \\
\hline Ash content \% & 1.98 & 1.76 & 1.87 \\
\hline Fiber \% & 1.79 & 3.3 & 3.42 \\
\hline Protein \% & 13.6 & 12.2 & 9.4 \\
\hline Gluten content $\%$ & 25.6 & 19.3 & - \\
\hline $\begin{array}{l}\text { Quality of Gluten units IDK (index } \\
\text { of deformation) of gluten }\end{array}$ & 80 II group Weak & 69- I group good & - \\
\hline Glassiness $\%$ & 38 & 21 & - \\
\hline Falling number sec. & 390 & 64 & 125 \\
\hline
\end{tabular}

\section{Results and Discussion}

At the first stage of research the grinding of the original grain of wheat and various wheat-triticale -rye grain milling mixtures was made on a grinding unit "Melnic 100 lux". To determine and compare the milling properties we processed the original grain of wheat and wheat - triticale - rye mixtures in proportions 50:40:10, 50:35:15 and 50:30:20. The obtained results of experimental grinding are shown on Table 2. According to the results of the tests, it can be concluded that the original grinding mixture of wheat, triticale and rye in proportions 50:40:10 is the most optimal since the yield of higher-grade flour and the total yield of flour from this grain mixture is the highest and exceeds not only the yield of all other grinding wheat-triticale-rye grain mixtures but also the control sample of the wheat. Besides, the flour obtained from that mixture has the highest whiteness typical of the higher grade flour. By analyzing the obtained data, it can be concluded that the quantity of gluten in the flour made from all mixtures, except the flour from the original wheat, does not meet the standards of GOST (State Standardization System) 26574-2017 "Wheat bread flour", since according to the standard the gluten content is $28 \%$ for the higher grade flour. However, the obtained data on the quantity of gluten in all mixtures meet the standards of GOST 34142-2017 "Triticale flour. Technical specifications". 
Table 2: Yield of wheat and wheat-triticale-rye bread flour.

\begin{tabular}{|c|c|c|c|c|c|}
\hline \multirow{2}{*}{ №№ of milling } & \multicolumn{5}{|c|}{ yield of flour, $\%$} \\
\hline & Higher Grade & Category 1 & Category 2 & Bran & Total \\
\hline №1 Original wheat & \multirow{2}{*}{43.9} & \multirow{2}{*}{-} & \multirow{2}{*}{27.5} & \multirow{2}{*}{28.6} & \multirow{2}{*}{100} \\
\hline №2 Grain mixture & & & & & \\
\hline of wheat-triticale-rye $50: 40: 10$ & \multirow{2}{*}{39.4} & \multirow{2}{*}{27.0} & \multirow{2}{*}{-} & \multirow{2}{*}{32.6} & \multirow{2}{*}{100} \\
\hline №3 Grain mixture & & & & & \\
\hline of wheat-triticale-rye 50:35:15 & \multirow{2}{*}{38.4} & \multirow{2}{*}{27.1} & \multirow{2}{*}{-} & \multirow{2}{*}{34.5} & \multirow{2}{*}{100} \\
\hline №4 Grain mixture & & & & & \\
\hline of wheat-triticale-rye $50: 30: 20$ & 37.7 & - & 27.2 & 35.1 & 100 \\
\hline
\end{tabular}

At the second stage of studies the baking properties of the original wheat and wheat- triticale- rye flour were specified. To study the baking properties of wheat and wheat-triticale-rye flour laboratory tests baking were carried out without dough. That method was developed by The Russian Center of assessment the quality of agricultural products [13]. The samples of the baked bread were tested on the total yield, shape stability, organoleptic indicators - appearance, dread pulp condition, taste, smell and physiochemical indicators - acidity and moisture of the bread crumb. The obtained results of the test laboratory baking are shown on Tables 3-6. The bread from wheat and wheat-triticale-rye flour had the total yield from 395 to $585 \mathrm{~cm} .3 / 100 \mathrm{gr}$. of flour. Table
6 demonstrates that all bread samples appearance and sourdough were rather highly rated. The surface of the bread from wheat and wheat-triticale-rye flour in proportion 50:40:10 is even, while from other types of wheat-triticale-rye flour (50:35:15 and 50:30:20) is a bit rough and lumpy. The color of wheat bread crust is brown with golden hue, and the other types are light brown (Figures 1-4). The crumb of all breads is light colored and elastic enough. All samples have fine porosity, thin-walled, uneven, except for the sample of bread from wheat-triticale-rye flour in the proportion of 50:40:10 it has even surface. All breads has taste and smells specific to wheat bread.

Table 3: Quality indicators of the obtained samples of higher-grade wheat and wheat-triticale-rye bread flour.

\begin{tabular}{|c|c|c|c|c|}
\hline Name of Indicator Mixture & $\begin{array}{c}\text { Grinding } 1 \\
\text { Flour From Original } \\
\text { Wheat }\end{array}$ & $\begin{array}{c}\text { Grinding } 2 \\
\text { Flour From Wheat- } \\
\text { Triticale-Rye 50:40:10 }\end{array}$ & $\begin{array}{c}\text { Grinding } 3 \\
\text { Flour From Wheat- } \\
\text { Triticale-Rye 50:35:15 }\end{array}$ & $\begin{array}{c}\text { Grinding } 4 \\
\text { Flour From Wheat- } \\
\text { Triticale-Rye 50:30:20 }\end{array}$ \\
\hline Moisture \% & 13.9 & 14.3 & 14.5 & 14.5 \\
\hline Whiteness \% & 55 & 65 & 62 & 60 \\
\hline Ash content \% & 0.53 & 0.53 & 0.52 & 0.50 \\
\hline Starch content \% & 68.6 & 67.5 & 64.8 & 64.9 \\
\hline Fat content \% & 1.1 & 1.0 & 1.0 & 0.97 \\
\hline Gluten quantity \% & 28.2 & 25.3 & 24.2 & 23.9 \\
\hline $\begin{array}{c}\text { Gluten quality (Index of } \\
\text { deformation of gluten) } \\
\text { Quality group }\end{array}$ & 64-I good & 56-I good & 57-I good & 62-I good \\
\hline Falling number, sec. & 313 & 327 & 320 & 313 \\
\hline $\begin{array}{c}\text { Size of grain milling \% } \\
\text { remains on the sieve. (№ } \\
\text { 45/50 PA) passage through } \\
\text { the sieve }\end{array}$ & $\begin{array}{r}0.5 \\
98.7\end{array}$ & $\begin{array}{c}1.51 \\
-\end{array}$ & 0.97 & 0.78 \\
\hline Color & \multicolumn{4}{|c|}{ white (or white with cream-colored hue) } \\
\hline Smell & \multicolumn{4}{|c|}{ typical of wheat-triticale-rye flour, without any foreign smell, neither musty nor moldy } \\
\hline Taste & \multicolumn{4}{|c|}{ typical of wheat-triticale-rye flour without any foreign aftertastes, neither sour nor bitter } \\
\hline
\end{tabular}


Table 4: Indicators of quality of the obtained samples of first-grade bread flour.

\begin{tabular}{|c|c|c|c|c|}
\hline Name of Indicator Mixture & $\begin{array}{c}\text { Grinding } 1 \text { Flour From } \\
\text { Original Wheat }\end{array}$ & $\begin{array}{c}\text { Grinding } 2 \text { Flour From } \\
\text { Wheat-Triticale-Rye } \\
50: 40: 10\end{array}$ & $\begin{array}{c}\text { Grinding } 3 \text { Flour From } \\
\text { Wheat-Triticale-Rye } \\
\text { 50:35:15 }\end{array}$ & $\begin{array}{c}\text { Grinding } 4 \text { Flour From } \\
\text { Wheat-Triticale-Rye } \\
\text { 50:30:20 }\end{array}$ \\
\hline Moisture \% & 13.5 & 14.1 & 14.3 & 14.2 \\
\hline Whiteness \% & 41 & 45 & 43 & 42 \\
\hline Ash content $\%$ & 0.70 & 0.75 & 0.76 & 0.78 \\
\hline Starch content $\%$ & 60.83 & 61.48 & 62.5 & 62.2 \\
\hline Fat content $\%$ & 1.2 & 1.17 & 1.12 & 1.11 \\
\hline Gluten quantity $\%$ & 29.64 & 22.36 & 23.12 & 23.4 \\
\hline $\begin{array}{l}\text { Gluten quality (Index of } \\
\text { deformation of gluten) }\end{array}$ & $66-\mathrm{I}$ & $72-\mathrm{I}$ & $65-\mathrm{I}$ & $63-\mathrm{I}$ \\
\hline Quality group & good & good & good & good \\
\hline Falling number, sec. & 353 & 372 & 369 & 366 \\
\hline $\begin{array}{l}\text { Size of grain milling remains } \\
\text { on the sieve (№ } 45 / 50 \text { PA) } \\
\text { passage through sieve }\end{array}$ & $\begin{array}{c}0.1 \\
98.7\end{array}$ & $\begin{array}{l}1.32 \\
98.3\end{array}$ & $\begin{array}{c}1.1 \\
98.6\end{array}$ & $\begin{array}{l}0.87 \\
98.4\end{array}$ \\
\hline Color & \multicolumn{4}{|c|}{ white (or white with cream-colored hue) } \\
\hline Smell & \multicolumn{4}{|c|}{ typical of wheat-triticale-rye flour, without any foreign smell, neither musty nor moldy } \\
\hline Taste & \multicolumn{4}{|c|}{ typical of wheat-triticale-rye flour without any foreign aftertastes, neither sour nor bitte } \\
\hline
\end{tabular}

Table 5: Indicators of bread quality made from various samples of wheat and wheat-triticale-rye flour.

\begin{tabular}{|c|c|c|c|c|}
\hline Name of Indicator Mixture & $\begin{array}{c}\text { Flour From Original } \\
\text { Wheat }\end{array}$ & $\begin{array}{c}\text { Flour From Wheat- } \\
\text { Triticale-Rye 50:40:10 }\end{array}$ & $\begin{array}{c}\text { Flour From Wheat- } \\
\text { Triticale-Rye 50:35:15 }\end{array}$ & $\begin{array}{c}\text { Flour From Wheat- } \\
\text { Triticale-Rye 50:30:20 }\end{array}$ \\
\hline Total yield of bread, $\mathrm{cm}^{3}$ & 580 & 500 & 475 & 390 \\
\hline Shape stability, h:d & 0.52 & 0.49 & 0.49 & 0.49 \\
\hline Porosity, $\%$ & 91 & 87 & 83 & 81 \\
\hline Crumb moisture, $\%$ & 44 & 43 & 43.4 & 43.7 \\
\hline Crumb acidity, grad. & 1.6 & 1.5 & 1.4 & 1.4 \\
\hline
\end{tabular}

Table 6: Quality indicators from the main flow of wheat and wheat-triticale-rye flour.

\begin{tabular}{|c|c|c|c|c|}
\hline Name of Indicator Mixture & $\begin{array}{c}\text { Flour From Original } \\
\text { Wheat }\end{array}$ & $\begin{array}{l}\text { Flour From Wheat- } \\
\text { Triticale-Rye 50:40:10 }\end{array}$ & $\begin{array}{l}\text { Flour From Wheat- } \\
\text { Triticale-Rye 50:35:15 }\end{array}$ & $\begin{array}{l}\text { Flour From Wheat- } \\
\text { Triticale-Rye 50:30:20 }\end{array}$ \\
\hline $\begin{array}{l}\text { Bread lumpy appearance, } \\
\text { shape }\end{array}$ & 4 - rough, lumpy & 4 - rough, lumpy & 3 - rough, lumpy & 3 - rough, lumpy \\
\hline Surface & 3 - semi oval & 4 - semi oval & 3 - semi oval & 3 - semi oval \\
\hline Crust color & 5 - golden- brown & 4 - light - brown & 4 - light - brown & 4 - light - brown \\
\hline Porosity & 4 - fine thin-walled, uneven & 4 - fine thin-walled, uneven & 4 - fine thin-walled, uneven & 4 - fine thin-walled, uneven \\
\hline elasticity elastic & 5- elastic quickly restored & 4 - less elastic well- restored & 4 - less elastic well- restored & 4 - less elastic well- restored \\
\hline Crust color & $\begin{array}{l}4 \text { - light or light with yellow } \\
\text { hue }\end{array}$ & $\begin{array}{l}4 \text { - light or light with yellow } \\
\text { hue }\end{array}$ & $\begin{array}{l}4 \text { - light or light with yellow } \\
\text { hue }\end{array}$ & $\begin{array}{l}4 \text { - light or light with yellow } \\
\text { hue }\end{array}$ \\
\hline Taste and for smell & 5 - specific for wheat bread & $\begin{array}{l}5 \text { - specific for wheat- } \\
\text { triticale- rye bread }\end{array}$ & $\begin{array}{l}5 \text { - specific for wheat- } \\
\text { triticale- rye bread }\end{array}$ & $\begin{array}{l}5 \text { - specific for wheat- } \\
\text { triticale- rye bread }\end{array}$ \\
\hline $\begin{array}{l}\text { Cumulative assessment. } \\
\text { points }\end{array}$ & 30 & 29 & 27 & 27 \\
\hline
\end{tabular}




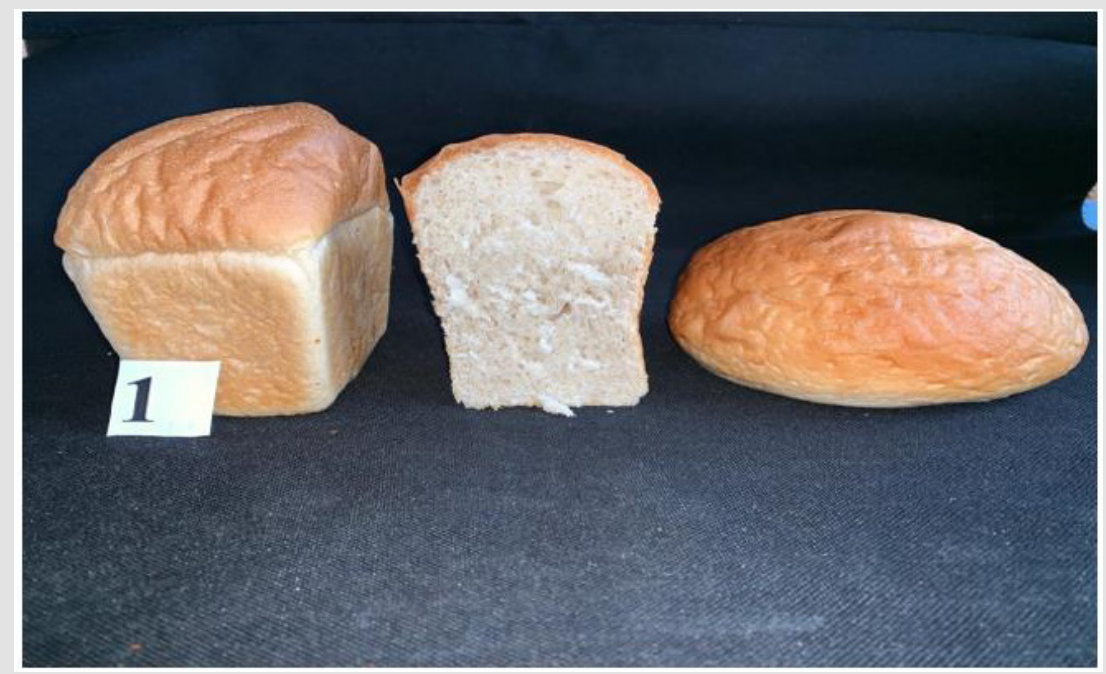

Figure 1: Bread from the original wheat flour.

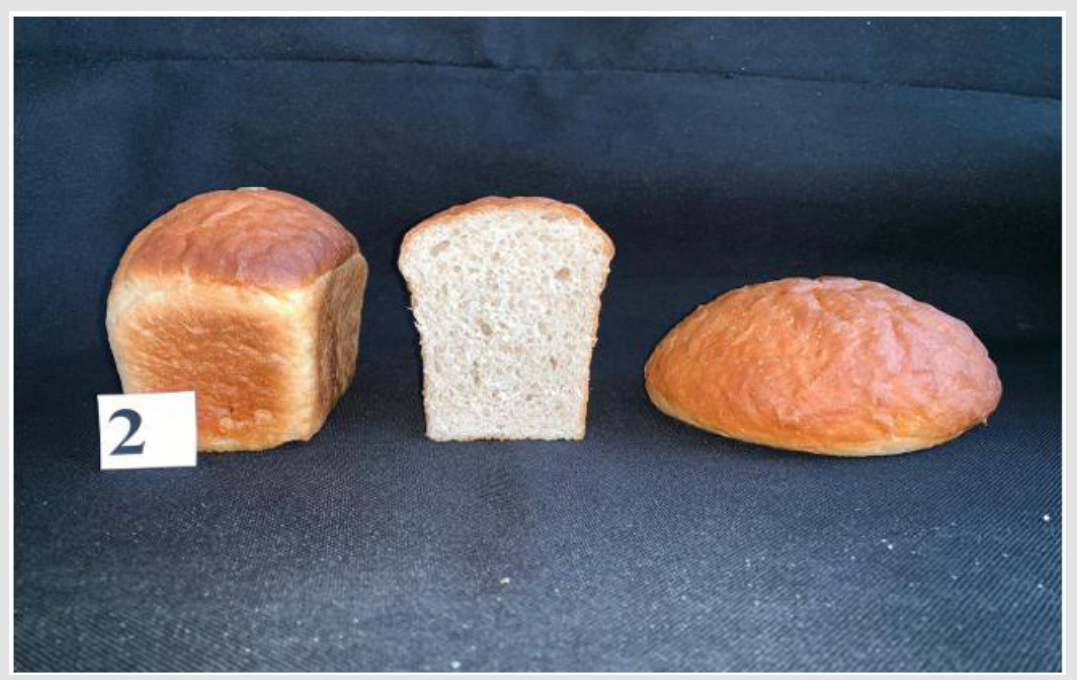

Figure 2: Bread from wheat-triticale-rye flour in proportions 50-40-10.

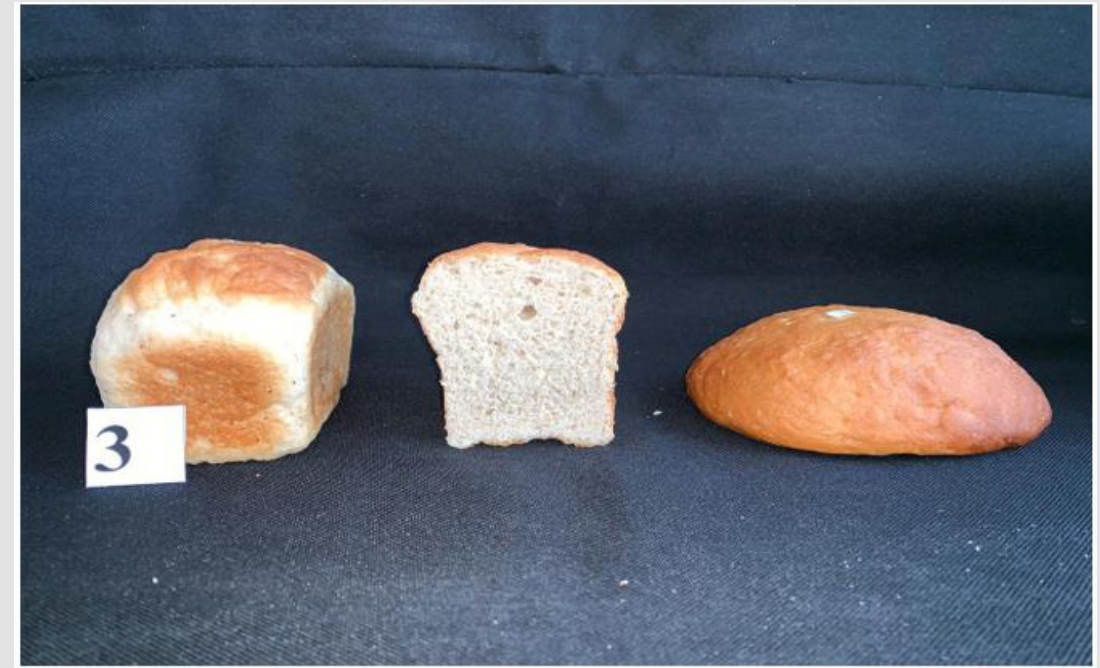

Figure 3: Bread from wheat-triticale-rye flour in proportions 50:35:15. 


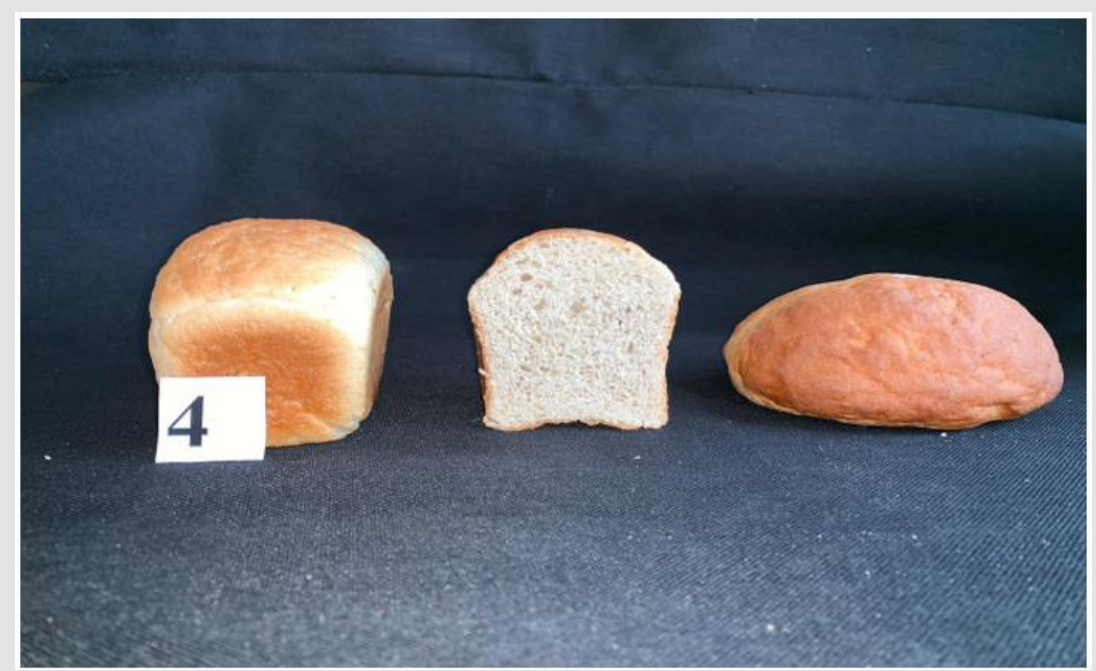

Figure 4: Bread from wheat-triticale-rye flour in proportions 50:30:20.

The maximum organoleptic assessment was 30 points of 35 possible the wheat bread sample can have. The wheat - triticale-rye bread from wheat flour in proportion 50:40:10 was a little behind with 29 points. According to the results of the test laboratory baking it can be concluded that the bread from wheat- triticalerye flour in proportion 50:40:10 is the most optimal in all tested quality indicators. It is a lot closer to the control variant in terms of moisture, porosity and acidity indicators in accordance with GOST 27842-88 "Wheat bread. Technical specifications". In organoleptic indicators it exceeds the samples from wheat-triticale-rye flour in proportion 50:35:15 and 50:30:20.

\section{Conclusion}

According to the results of the conducted tests the milling properties of the grinding grain mixture from wheat and wheattriticale-rye grain in various proportions were determined. The tests were carried out at the "Melnic 100 lux" industrial mill. According to the results of the complex study it can be concluded that the grinding mixture of wheat and wheat-triticale-rye grain in proportion 50:40:10 is the most optimal since the yield and quality of the higher-grade flour and the total yield of flour from this grain mixture exceeds all other grinding mixtures and the control sample of the original wheat. In addition, the flour obtained from that mixture has the highest whiteness. The laboratory baking tests were carried out to determine the baking properties of the obtained samples of wheat and wheat-triticale-rye flour. As a result, the bread from wheat-triticale-rye flour in proportions 50:40:10, got the top rating in terms of organoleptic and physiochemical indicators. The obtained new bread from that flour will be healthier compared to the one made from wheat since it will differ in terms of digestibility, higher protein content with the limiting indispensable amino acid-lysine.

\section{Conflict of interest}

The authors declare no conflict of interest.

\section{References}

1. Andreev NR, Kolpkakova VV, Goldestein VG (2018) On the issue of deep processing of triticale grains. Food Industry 9: 30-33.

2. Kandrokov R Kh, Pankratov GN (2017) Technology for processing triticale grains into semolina type cereals. Bread products 1(S): 52-53.

3. Kandrokov R Kh (2019) Development of an effective technological scheme for processing triticale grain into high-quality baking flour / R.Kh. Kandrokov, G.N. Pankratov. Russian Agricultural Science T1(1): 62-65.

4. Meleshkina EP (2017) Technological and biochemical indicators as components of the quality of triticale flour / E.P. Meleshkina, G.N. Pankratov, R.Kh. Kandrokov, Vitol I.S. Quality control of products 2S: 3844.

5. Meleshkina E P, Pankratov GN, Pankratieva IA, Chirkova LV, Kandrokov R Kh, et al. (2018) Triticale (R.H. processing technology). Monograph / (Ed). E P Meleshkina M: Publishing House of the Flint pp. 188

6. Tulyakov DG, Meleshkina EP, Vitol IS, Pankratov GN, Kandrokov R Kh (2017) Evaluation of the properties of flour from triticale grains using the Mixolab system. Storage and processing of agricultural raw materials 1: 20-23.

7. Axford DWE, McDermott EE, Redman DG (1978) Small-scale tests of breadmaking quality. Milling Feed Fert 16(5): 18.

8. Bona L, Acs E, Lantos C, Purnhauser L, Lango B, et al. (2013) Human utilization of triticale: technological and features, milling and baking experiments. In: Abstracts 8th international triticale symposium. Ghent, Belgium: 79(4): 139-152.

9. Brzezinski W (2011) Electrophoretic patterns of wheat, triticale, barley and oat cultivars registered in 2007-2011. Wiadomosci Odmianoznawcze z. 85. COBORU ed. pp 1-23.

10. Brzezinski W, Lukaszewski AJ (1998) Allelic variation at the Glu-1, Sec-2 and Sec-3 loci in winter triticale. In: Proceedings of 4-th international triticale symposium, Red Deer, Alberta, Canada. P.6-12.

11. Ceglinska A, Cichy H, Cacak-Pietrzak G, Haber T, Smuga W, et al. (2006) Folia Univ Agric Stetin Agricultura 247 (100): 39-44. 
12. Cooper KV (1985) The Australian triticale cookery book, pp: 1-79.

13. Dhaliwal AS, McRitchie F (1990) Contribution of protein fractions to dough handling properties of wheat/rye translocations cultivars. Cereal Sci 12(2): 113-122.

14. Grabovets AI (2012) Triticale. Genetics, breeding, agrotechnics, technology of using grain and green forage, 5 edn. Rostov on Don pp 1-231.

15. Grabovets AI, Krohmal AV, Kopus MM (2010) Triticale. Genetics, breeding, agrotechnics, using grain and green forage. Rostov on Don pp: 57-64.

16. Grabovets AI, Krokhmal AV, Dremucheva GF, Karchevskaya OE (2013) Breeding of triticale for baking purposes. Russ Agric Sci 39: 197-202.

17. He ML, McAllister TA, Hernandez-Calva LM, Aalhus JL, Dugan MER, et al. (2014) Effect of dietary inclusion of triticale dried distillers' grain and oilseeds on quality and fatty acid profile of meat from feedlot steers. Meat Sci 97(1): 76-82.

18. Kandrokov RH, Pankratov GN, Meleshkina EP, Vitol IS, Tulyakov DG (2019) Effective technological scheme for processing triticale grain into high-quality baker's grade flour. Foods and Raw Materials 7(1): 107-117.

19. Klockiewicz-Kamińska E, Brzeziński W (1997) Breadmaking quality testing and wheat varieties classification in Poland. In: Gacek E (ed), COBORU Slupia Wielka, Poland 67: 1-18.

\section{ISSN: 2574-1241}

DOI: 10.26717/BJSTR.2021.39.006305

Roman Khazhsetovich Kandrokov. Biomed J Sci \& Tech Res

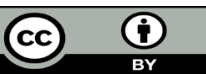

This work is licensed under Creative Commons Attribution 4.0 License

Submission Link: https://biomedres.us/submit-manuscript.php
20. Lukaszewski AJ (1998) Improvement of breadmaking quality of triticale through chromosome translocations. In: Proceedings of $4^{\text {th }}$ international Triticale Symposium, Red Deer, Canada, pp: 102-110.

21. Lukaszewski AJ (2006) Cytogenetically engineered rye chromosomes $1 \mathrm{R}$ to improve bread-making quality of hexaploid triticale. Crop Sci 46(5): 2183-2194.

22. Manley M, McGoverin C, Snyders F, Muller N, Botes W, et al. (2013) Prediction of triticale grain quality properties, based on both chemical and indirectly measured reference methods using near-infrared spectroscopy. Cereal Chem 90(6): 540-545.

23. Marciniak A, Obuchowski W, Makowska A (2008) Technological and nutritional aspects of utilisation of triticale for extruded food production, EJPAU 11(4): №04.

24. Meleshkina EP, Pankratov GN, Vitol IS, Kandrokov RH, Tulyakov DG, et al. (2017) Innovative Trends in the Development of Advanced Triticale Grain Processing Technology. Foods and Raw Materials 5(2): 70-82.

25. Pena RJ, Mergoum M, Pfeiffer WH (1998) Glutenin subunit composition and breadmaking quality characteristics of recently developed triticale germplasm of CIMMYT. In: Proceedings of $4^{\text {th }}$ international triticale symposium, Red Deer, Canada, pp: 117-123.

26. Rogovsky PM, Guidet FLY, Langridge P, Shepherd KW, Koebner RMD, et al. (1991) Isolation and characterization of wheat-rye recombinants involving chromosome arm 1DS of wheat. Theor Appl Genet 82(5): 537544 .

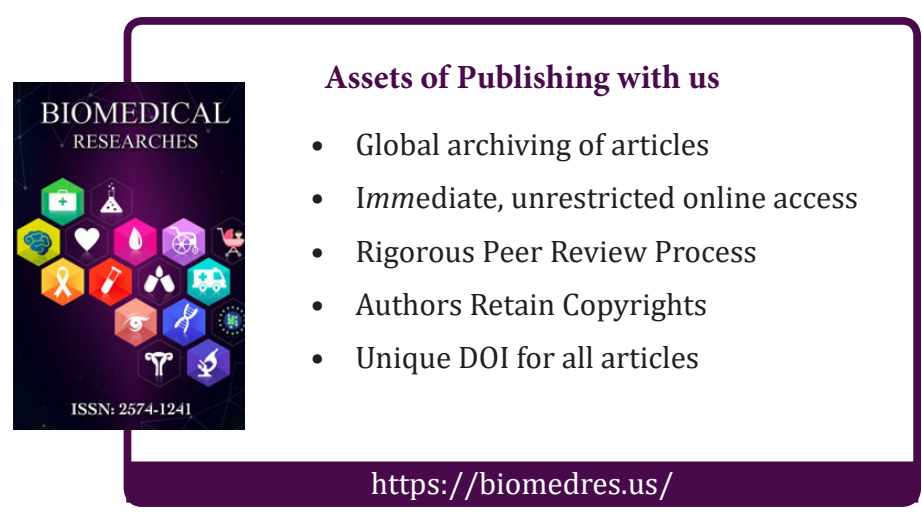

